\title{
Inactivation of tumor suppressor Dlg I augments transformation of a T-cell line induced by human T-cell leukemia virus type I Tax protein
}

\author{
Kojiro Ishioka ${ }^{\dagger 1,2}$, Masaya Higuchi ${ }^{\dagger 1}$, Masahiko Takahashi ${ }^{1}$, \\ Sakiko Yoshida ${ }^{1,3}$, Masayasu Oie ${ }^{1}$, Yuetsu Tanaka ${ }^{4}$, Sugata Takahashi², \\ $\mathrm{Li} \mathrm{Xie}^{5}$, Patrick L Green ${ }^{5}$ and Masahiro Fujii*1
}

\begin{abstract}
Address: ${ }^{1}$ Division of Virology, Niigata University Graduate School of Medical and Dental Sciences, 1-757 Asahimachi-Dori, Niigata, Japan, ${ }^{2}$ Division of Otolaryngology, Niigata University Graduate School of Medical and Dental Sciences, 1-757 Asahimachi-Dori, Niigata, Japan, ${ }^{3}$ Division of Pediatrics, Niigata University Graduate School of Medical and Dental Sciences, 1-757 Asahimachi-Dori, Niigata, Japan, ${ }^{4}$ Department of Infectious Disease and Immunology, Okinawa-Asia Research Center of Medical Science, Faculty of Medicine, University of the Ryukyus, Okinawa, Japan and ${ }^{5}$ Department of Veterinary Biosciences, The Ohio State University, 1925 Coffey Road, Columbus, USA

Email: Kojiro Ishioka - kojiro1@med.niigata-u.ac.jp; Masaya Higuchi - mhiguchi@med.niigata-u.ac.jp; Masahiko Takahashi - masahiko@med.niigata-u.ac.jp; Sakiko Yoshida - sakikoy9@med.niigata-u.ac.jp; Masayasu Oie - moie@med.niigatau.ac.jp; Yuetsu Tanaka - yuetsu@ma.kcom.ne.jp; Sugata Takahashi - sugata@med.niigata-u.ac.jp; Li Xie - xie.38@osu.edu; Patrick L Green - green.466@osu.edu; Masahiro Fujii* - fujiimas@med.niigata-u.ac.jp

* Corresponding author †Equal contributors
\end{abstract}

Published: 17 October 2006

Retrovirology 2006, 3:71 doi:10.1I86/I742-4690-3-7I
Received: 20 June 2006

Accepted: 17 October 2006

This article is available from: http://www.retrovirology.com/content/3/I/7I

(C) 2006 Ishioka et al; licensee BioMed Central Ltd.

This is an Open Access article distributed under the terms of the Creative Commons Attribution License (http://creativecommons.org/licenses/by/2.0), which permits unrestricted use, distribution, and reproduction in any medium, provided the original work is properly cited.

\begin{abstract}
Background: The interaction of human T-cell leukemia virus type I (HTLV-I) TaxI protein with the tumor suppressor $\mathrm{DIgI}$ is correlated with cellular transformation.

Results: Here, we show that DIgI knockdown by RNA interference increases the ability of TaxI to transform a mouse T-cell line (CTLL-2), as measured interleukin (IL)-2-independent growth. A TaxI mutant defective for the DIgI interaction showed reduced transformation of CTLL-2 compared to wild type TaxI, but the transformation was minimally affected by DIgI reduction. The few TaxI $\triangle$ C-transduced CTLL-2 cells that became transformed expressed less DIgI than parental cells, suggesting that $\mathrm{DIgI-low}$ cells were selectively transformed by $\operatorname{Tax} I \Delta C$. Moreover, all human T-cell lines immortalized by HTLV-I, including the recombinant HTLV-I-containing TaxI $\Delta \mathrm{C}$, expressed less DIgI than control T-cell lines.
\end{abstract}

Conclusion: These results suggest that inactivation of D|gl augments Taxl-mediated transformation of CTLL-2, and PDZ protein(s) other than DIgl are critically involved in the transformation.

\section{Background}

Adult T-cell leukemia (ATL) is an aggressive leukemia that originates mostly from CD4+ T-cells [1-3]. Human T-cell leukemia virus type 1 (HTLV-1) is a causative retrovirus of
ATL $[4,5]$. HTLV-1 immortalizes human CD4+ T-cells in vitro and probably does so in vivo, but such immortalization is not sufficient for the development of ATL, since only $3-5 \%$ of HTLV-1 infection causes ATL after long- 
latent period of $60-70$ years $[1-3,6,7]$. Multiple genetic and epigenetic changes in HTLV-1-infected cells and deterioration of host immune system during the latent period, are thought to be prerequisite for the development of ATL [3].

HTLV-1 Tax1 is a key player, involved in both T-cell immortalization as well as the leukemogenesis, and it shows transforming activities in various systems $[8,9]$. Transduction of the tax 1 gene into peripheral blood mononuclear cells using viral vectors induces interleukin(IL)-2-dependent immortalization of CD4+ T-cells in vitro $[10,11]$. In vivo, Tax1-transgenic animals develop various tumors including pre-T-cell leukemia [12-14]. Tax1 also perturbs cellular gene expression, in part, through activation of transcription factors such as NF- $k \mathrm{~B}$, serum response factor, and AP-1, thereby inducing the expression of genes encoding cytokines, cytokine receptors, chemokines, and anti-apoptotic factors [8,15-20].

HTLV Type 2 (HTLV-2) is a retrovirus that is similar in many respects to HTLV-1 [21]. For instance, HTLV-2 establishes life-long persistent infection in humans and immortalizes human T-cells in an efficiency equivalent to HTLV-1 in vitro. Interestingly, HTLV-2 is not, associated with ATL or related malignancies and has been associated with only a few cases of lymphoproliferative disorders. Recent evidence suggested that the PDZ protein binding motif (PBM) at the C-terminus of Tax1, which is missing in HTLV-2 Tax2, plays a crucial role in the distinct pathogenesis between HTLV-1 and HTLV-2 [8,21-25]. For instance, the transforming ability of Tax 1 is much greater than Tax2 in a mouse T-cell line (CTLL-2), and this difference appears to be determined by the PBM [23,25]. A recombinant HTLV-1 with a deletion of the PBM (HTLV$1 \triangle \mathrm{PBM}$ ) failed to establish persistent infection in rabbits, as measured by the lack of antibody responses against HTLV-1 and the absence of HTLV-1 proviruses [24]. Interestingly, HTLV-1 $\triangle \mathrm{PBM}$ can transform human T-cells, although in a less efficient manner than the wild type virus, suggesting that the Tax1 PBM is essential for persistent infection in vivo, but dispensable for the transformation of human T-cells.

The PBM of HTLV-1 Tax1 interacts with several PDZ proteins such as Dlg1, the precursor of IL-16, and MAGI-3 $[23,26-30]$. Among these, Dlg1 is an attractive candidate associated with the transforming activity of Tax1. Dlg originally was isolated from Drosophila and was shown to be a tumor suppressor gene. Loss-of-function mutations in Dlg1 in Drosophila resulted in the neoplastic overgrowth of imaginal disc epithelial cells [31]. Dlg1 also is a tumor suppressor gene in mice, such that Dlg1 heterozygous mice develop B-cell or NK cell lymphomas [32]. Moreover, over-expression of Dlg1 induced cell cycle arrest of a mouse fibroblast cell line NIH3T3, and the arrest was rescued by Tax1 in a PBM-dependent manner [28].

CTLL-2 is a mouse T-cell line, the growth of which is dependent on IL-2. We previously showed that Tax 1 abrogates the IL-2-dependent growth phenotype of CTLL-2 [33]. Whereas expression of Tax1 often induces cell growth arrest [34], CTLL-2 is resistant to such Tax1 activity, thereby being a useful tool to examine the transforming activity of Tax 1 toward T-cells. In the study reported here, knockdown of D1g1 with RNA interference (RNAi) enhanced the ability of Tax 1 to induce IL-2 independence in CTLL-2 cells. Moreover, Dlg1 expression was significantly less in all HTLV-1-transformed T-cell lines compared to HTLV-1-negative cell lines, suggesting that inactivation of Dlg1 is a critical step for transforming activity of Tax1. We will discuss these findings in the context of T-cell transformation by HTLV-1.

\section{Results \\ DIgI knockdown augments the ability of TaxI to induce IL-2-independent growth in CTLL-2 cells}

To examine the roles of Dlg1 protein in Tax1-induced IL2-independent growth of CTLL-2 cells, we established CTLL-2 cells expressing reduced amount of Dlg1 using RNA interference (RNAi). We first constructed lentivirus vectors expressing short hairpin (sh)RNA specific to mouse dlg1 sequences (Dlg1-1, Dlg1-3). Dlg1-1 and Dlg1-3 target distinct sequences of mouse Dlg1 RNA. Two control shRNAs were constructed to target bacterial chloramphenicol acetyltransferase (CAT) and renilla luciferase (LUC) genes, both of which are not expressed normally in mouse T-cells. These viruses were used to infect CTLL-2 cells, and the infected cells were selected by blasticidin for more than 10 days. The established cell lines then were examined for the expression of Dlg1 protein by Western blotting analysis with anti-Dlg1 antibody (Figure 1). Two Dlg1 knockdown cell lines (Dlg1-1, Dlg1-3) expressed a reduced amount of Dlg1 protein relative to two control cell lines (CAT, LUC). These four cell lines grew at equivalent rates in the presence of IL-2 (Figure 1B), and died without IL-2 with similar kinetics (data not shown). Thus, the reduction of Dlg1 expression in CTLL-2 cells did not affect apparent cell growth phenotypes. To examine the effect of Dlg1 knockdown on Tax1-induced IL-2-independent growth, these characterized Dlg1 knockdown cell lines were infected with a lentivirus expressing Tax1 (Tax1-virus) and cultured in the presence of IL-2 for $48 \mathrm{~h}$. Subsequently, the cells were seeded into 96-well plates, followed by further culturing in the absence of IL-2. After more than two weeks, the number of wells with outgrowing CTLL-2 cells was counted using a microscope. All CTLL-2 cells infected with a control lentivirus died within two weeks and did not induce any outgrowing cells (data not shown). Conversely, there was an outgrowth of con- 
A)

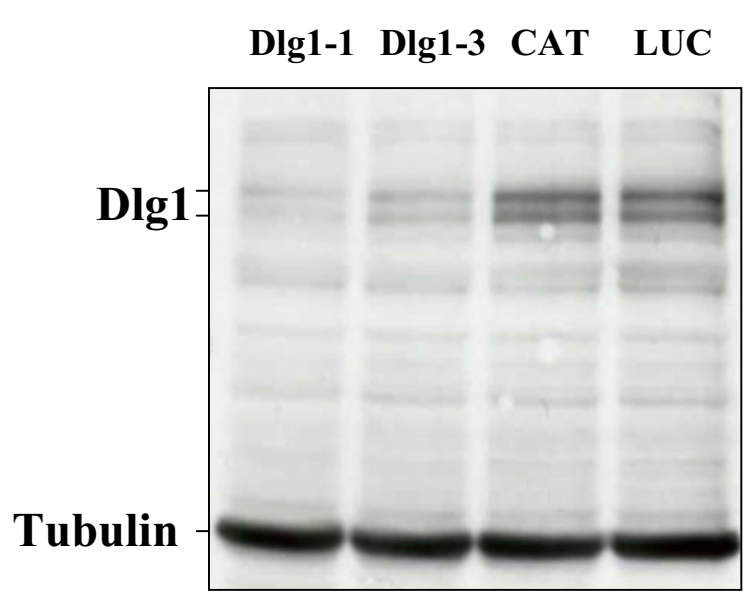

B)

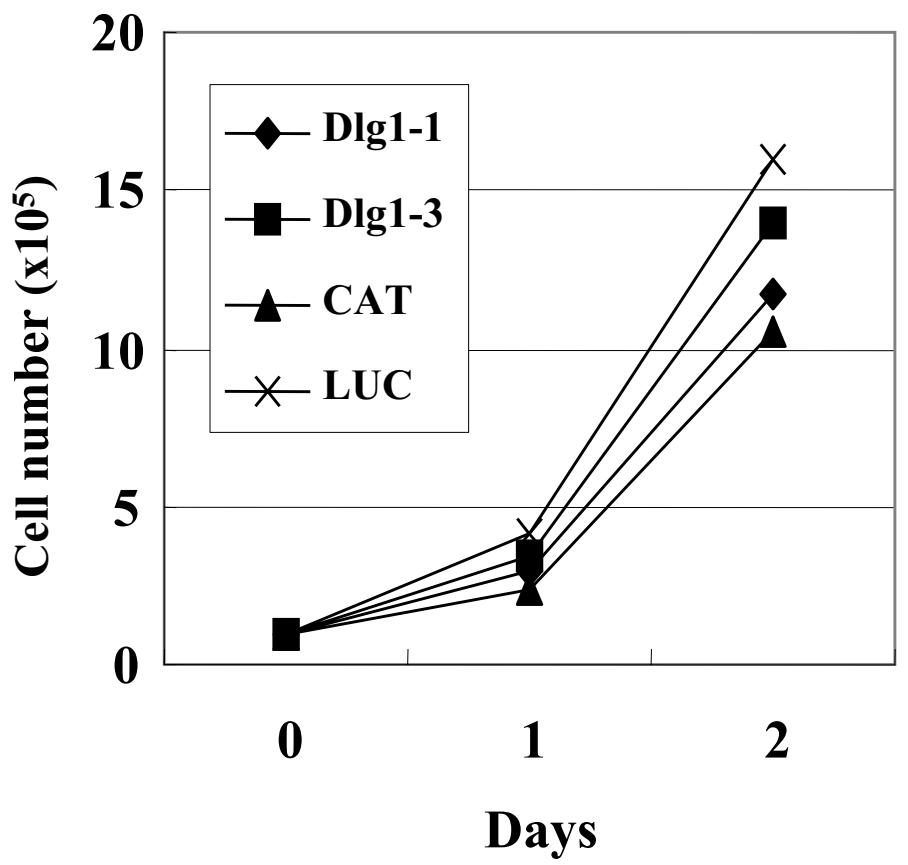

\section{Figure I}

DIg I knockdown in CTLL-2 does not affect the cell growth phenotypes. (A) CTLL-2 cells infected with lentivirus expressing shRNA for DIgl-I (lane I), DIgl-3 (lane 2), CAT (lane 3) and LUC (lane 4), were cultured in the presence of blasticidin for more than 10 days. Cell lysates then were prepared and characterized by Western blot analysis using anti-Dlg I antibody (top) or anti-Tubulin (bottom). (B) The CTLL-2 cells were cultured in the presence of IL-2 and counted by trypan blue exclusion method.

trol CTLL-2 infected with the Tax1-virus (CAT/Tax1, LUC/ Tax 1 ) at $7-11 \%$ of wells (Figure 2). Similarly, Dlg1 knockdown cells infected with the Tax1-virus (Dlg1-1, Dlg1-3) also had outgrowth with three to six-folds more wells than the controls (CAT/Tax1, LUC/Tax1). The observed differences were not due to reduced Tax1 expression in the control cells, since all four cell lines expressed equivalent amounts of Tax 1 protein after the infection as shown by Western analysis (Figure 2A). The augmented Tax 1 activity was reproducibly observed in at least nine independent experiments (data not shown). The Dlg1-1 and Dlg1-3 cell lines established by independent experiments also reproduced the high sensitivity to Tax 1 transformation relative to control cells (data not shown). Taken together, these results indicate that the reduction of Dlg1 protein in CTLL-2 augmented the ability of Tax 1 to induce IL-2 independent growth.

\section{DIgI knockdown doesn't augment TaxI $\triangle \mathrm{C}$ activity in CTLL-2}

We previously showed that Tax1 interacts with Dlg1 through PBM, and the deletion of PBM in Tax1 (Tax1 $\Delta \mathrm{C}$ ) greatly reduced IL-2-independent growth mediated by Tax1 in CTLL-2 [25]. These results suggest that wild type Tax1 inhibits the tumor suppressor-like activity of Dlg1 through direct binding via the PBM while Tax $1 \Delta \mathrm{C}$ cannot, resulting in the reduced transforming activity. Therefore, we examined whether Dlg1 knockdown could rescue the transforming activity of $\operatorname{Tax} 1 \Delta \mathrm{C}$. $\operatorname{Tax} 1 \Delta \mathrm{C}$ also induced the outgrowth of control CTLL-2 cells (CAT), but the number of positive wells was much less than that of Tax 1 , which was consistent with the previous result [25]. It should be noted that $1 \times 10^{5}$ CTLL-2 cells infected with Tax $1 \Delta$ C-virus or $3 \times 10^{2}$ cells with Tax1-virus were seeded per well, indicating that the actual transforming activity of Tax 1 versus $\mathrm{Tax} 1 \triangle \mathrm{C}$ in CTLL-2 cells was much greater than the observed relative difference. Tax $1 \Delta \mathrm{C}$ in the Dlg 1 knockdown cells also induced outgrowth, and the number of positive wells was similar to that of the control cells (Figure $3 \mathrm{~B}$ ). These results suggest that inactivation of Dlg1 alone does not explain the difference in transforming activity between $\operatorname{Tax} 1$ and $\operatorname{Tax} 1 \Delta$. All four IL-2-independent $\operatorname{Tax} 1 \Delta \mathrm{C}$ cell lines (Dlg1-1/Tax1 $\Delta \mathrm{C}$, Dlg1-3/Tax1 $\Delta \mathrm{C}$, $\mathrm{CAT} / \operatorname{Tax} 1 \Delta \mathrm{C}$, LUC/Tax $1 \Delta \mathrm{C}$ ) grew much more slowly than 


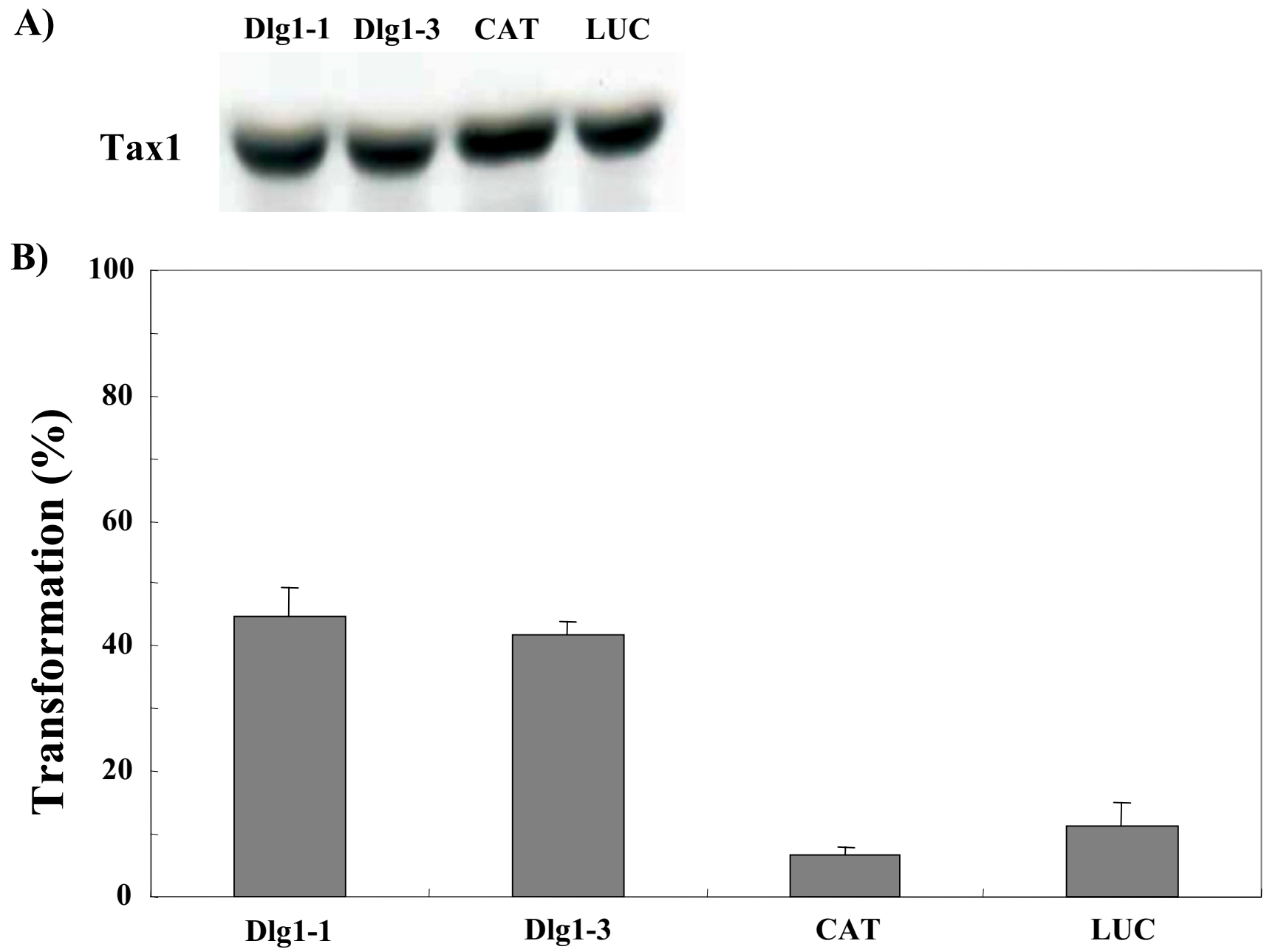

Figure 2

DIg I knockdown augments IL-2-independent cell growth induced by TaxI. (A) CTLL-2 cells were infected with a lentivirus encoding Taxl. Forty-eight hours after infection, cell lysates were prepared and the amount of Taxl in the lysates was measured by Western blot analysis using an anti-Taxl antibody. (B) CTLL-2 cells (DIgI-I, DIgI-3, CAT, LUC) infected with Taxl-virus were washed twice with PBS, seeded into 96-well plates at $3 \times 10^{2}$ cells per well, and cultured in the absence of IL-2 for four weeks. The number of wells containing outgrowing cells was counted under a light microscope. Transformation efficiency (\%) was calculated as a ratio of the number of positive wells out of 96 wells. Error bars indicate standard deviations in three independent experiments.

the IL-2-independent Tax1 cell lines (Figure 4B), suggesting that Tax1 PBM has another function in cell growth as discussed below.

\section{Reduced expression of DIgl in Taxl-transformed cells}

To confirm the effect of D1g1 knockdown, we examined the expression of Dlg1 in the cells characterized above. Western blot analysis with anti-Dlg1 antibody demonstrated reduced expression of Dlg1 in the Dlg1 knockdown cells (Dlg1-1, Dlg1-3) even after IL-2-independent transformation by $\operatorname{Tax} 1$ or $\operatorname{Tax} 1 \Delta \mathrm{C}$ (Figure $4 \mathrm{~A}$ ). Interestingly, IL-2-independent control cells (CAT, LUC) transformed either by Tax $1 \Delta \mathrm{C}$ or Tax 1 expressed less Dlg1 compared to the parental non-transformed cells, and the reduction of Dlg1 was much more prominent in Tax $1 \Delta \mathrm{C}$ cells relative to Tax1. These results support a hypothesis that IL-2-independent transformation of CTLL-2 cells by $\operatorname{Tax} 1 \Delta \mathrm{C}$ requires reduction of $\mathrm{Dlg} 1$ expression. In the above experiments, we used bulk (non-clonal) CTLL-2 cells transformed by Tax $1 \Delta \mathrm{C}$ or Tax1, which were established in culture flasks. To examine this hypothesis further, we evaluated five independent clonal CTLL-2 cell lines transformed either by $\operatorname{Tax} 1 \Delta \mathrm{C}$ or Tax 1 established in 96-well plates and compared the expression level of Dlg1 protein in these cloned cells (Fig 5). All five IL-2-independent $\operatorname{Tax} 1 \Delta \mathrm{C}$ clones expressed reduced amounts of 


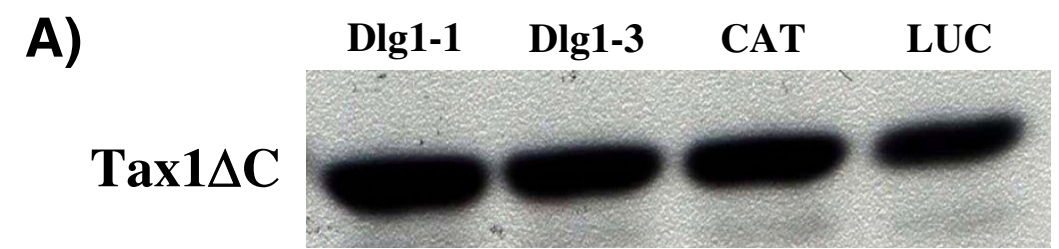

B)

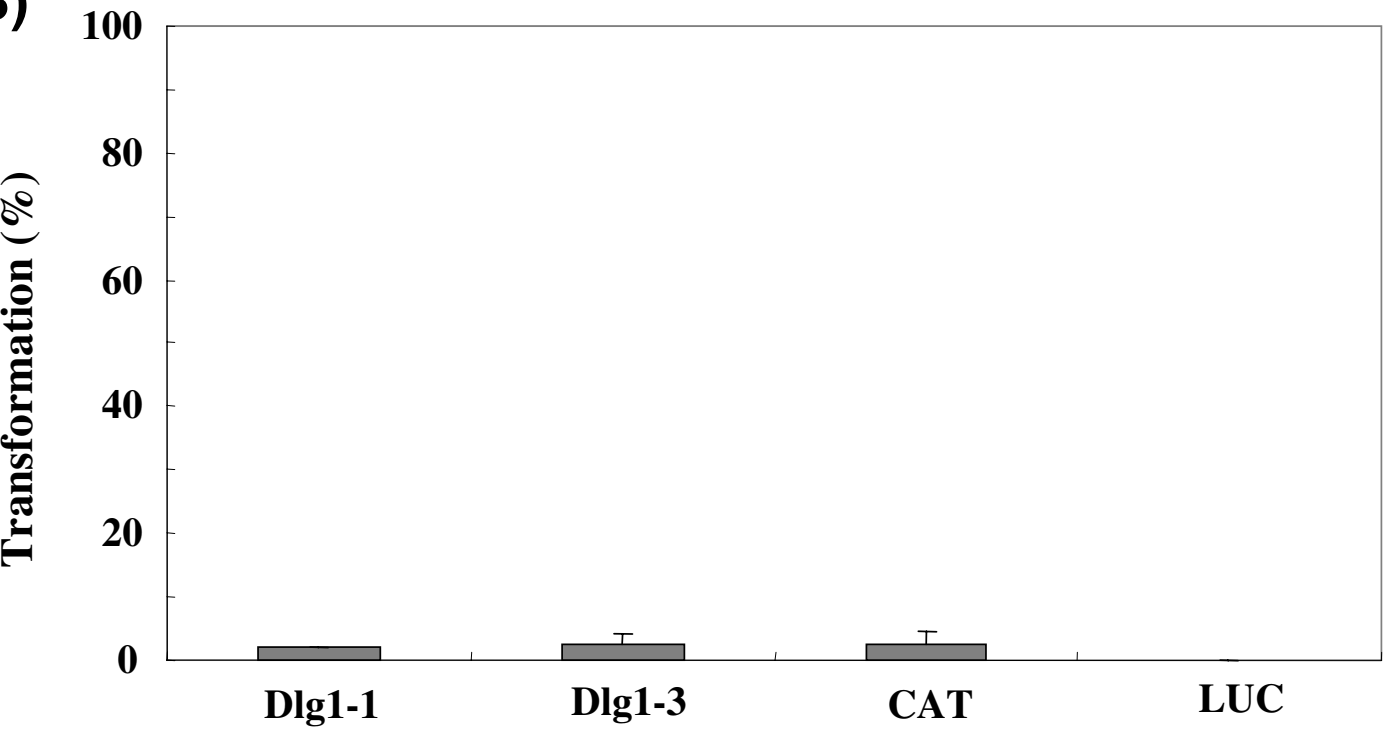

Figure 3

DIg I knockdown does not augment IL-2-independent cell growth induced by Tax I $\Delta$ C. (A) CTLL-2 cells were infected with a lentivirus encoding $\operatorname{Tax} I \Delta C$. Forty-eight hours after infection, cell lysates were prepared and the amount of $\operatorname{Tax} I \Delta C$ in the lysates was measured by Western blot analysis using an anti-Taxl antibody. (B) CTLL-2 cells (DlgI-I, DlgI-3, CAT, LUC) infected with Taxl $\Delta$ C-virus were washed twice with PBS, seeded into 96 -well plates at $5 \times 10^{3}$ cells per well and cultured in the absence of IL-2 for four weeks. The number of wells containing outgrowing cells was counted under a light microscope. Transformation efficiency (\%) was calculated as a ratio of the number of positive wells out of 96 wells. Error bars indicate standard deviations in three independent experiments.

Dlg1, whereas two out of five Tax1 clones expressed Dlg1 at a level similar to Tax $1 \Delta \mathrm{C}$. The expression of Syntrophin $\beta$, another PDZ protein suggested to interact with Tax1 [27], was expressed equivalently in these cell lines, indicating that reduced expression of Dlg1 in Tax $1 \Delta \mathrm{C}$ is specific. These data lend additional support to the hypothesis that reduced expression of Dlg1 protein is a factor required for Tax $1 \Delta \mathrm{C}$-induced IL-2-independent transformation of CTLL-2 cells.

We also examined the expression of Dlg1 protein in HTLV-1-transformed T-cell lines (Figure 6). All seven HTLV-1-transformed T-cell lines, including one transformed by HTLV-1 $\triangle$ PBM with a deletion of the Tax1 PBM, expressed lower amounts of Dlg1 than three HTLV-1 neg- ative human T-cell lines. These results suggest that the Dlg1-low phenotype is preferential for HTLV-1-mediated transformation of human T-cells. The molecular weight of Dlg1 in three HTLV-1-infected T-cell lines (ILT-Koy, SLB1, HUT-102) that express high amounts of Tax1 was greater than that in HTLV-1 negative T-cell lines, which corresponds to the phosphorylation of Dlg1 in HTLV-1infected T-cell lines [28]. The biological relevance of phosphorylated Dlg1 in HTLV-1-transformed cells is unclear [25].

Effect of DIg I knockdown on Tax I transcriptional activity We next examined the effect of Dlg1 knockdown on Tax1 transcriptional activity. To do so, Jurkat cells were infected with lentivirus expressing shRNA against human dlg1 


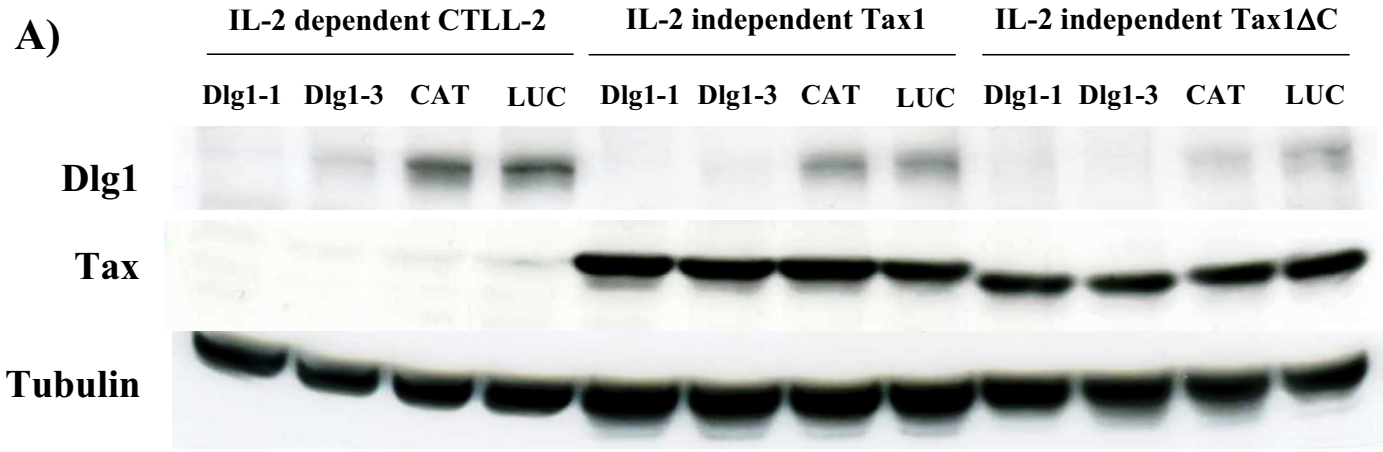

B)

$\operatorname{Tax} 1$

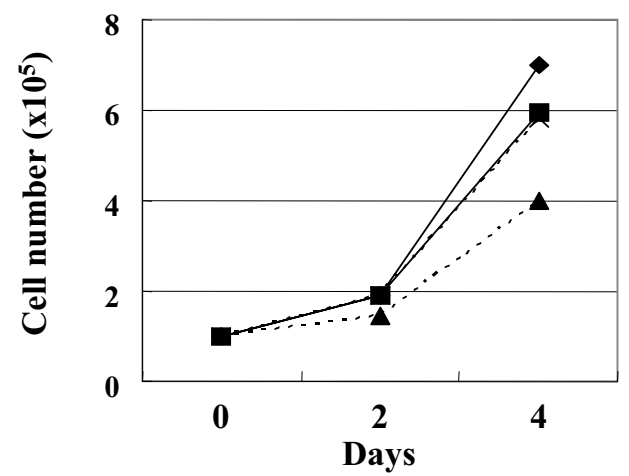

$\operatorname{Tax} 1 \Delta \mathrm{C}$

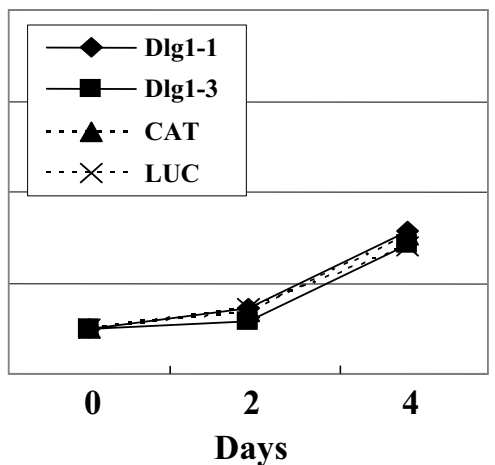

\section{Figure 4}

Low DIgI expression in IL-2-independent Tax I $\Delta$ C cells. (A) CTLL-2 cells (DIgI-I, DIgI-3, CAT, LUC) were infected with TaxI-virus (lanes 5-8) or TaxI $\Delta \mathrm{C}$ (lanes 9-12), and cultured in the absence of IL-2 for more than one month in culture flasks. Expression of DIgI (top), TaxI (middle) and Tubulin (bottom) in parental IL-2-dependent CTLL-2 (lanes I-4), TaxItransformed CTLL-2 (lanes 5-8) and TaxI $\Delta$ C-transformed CTLL-2 (lane 9-12), was measured by Western blot analysis. (B) Cells were cultured in the absence of IL-2 and counted by trypan blue staining. Data are representative of two independent experiments.

(hDlg1). Western blotting analysis showed that two hDlg1 knockdown cell lines (hDlg1-1, hDlg1-3) expressed a reduced amount of Dlg1 protein relative to a control cell line (Rluc) targeting a renilla luciferase gene (Figure 7A). These cell lines were then transfected with a Tax1 expression plasmid together with a firefly luciferase reporter plasmid regulated by the $\mathrm{NF}-\mathrm{KB}$ site, which acts as a Tax1-inducible element, by the lipofection method. Tax1 efficiently activated NF- $\kappa \mathrm{B}$-dependent luciferase activity in two hDlg1 knockdown cells, and the activities were equivalent to those in the control cells (Rluc, None). These results indicates that reduction of hDlg1 protein little affects Tax 1 dependent NF- $\kappa \mathrm{B}$ activation in T-cells.

\section{Discussion}

HTLV-1 Tax1 interacts with Dlg1 through PBM in various experimental conditions as well as in HTLV-1-infected Tcell lines, and the interaction is well correlated with transforming activity of Tax $1[23,25,26,28,35]$. However, it has been unclear whether and how Dlg1 plays a role in Tax1mediated cellular transformation. Two lines of evidence suggested that inactivation of Dlg1 is a critical step for the transforming activity of Tax1, and Tax1 through PBM inactivates inhibitory activity of Dlg1 to induce transformation of CTLL-2 cells (Figure 2). First, Dlg1 knockdown in CTLL-2 cells increased their ability to be transformed by Tax1 (Figure 2). Second, Tax1 $\Delta$ C-transformed cells, which 


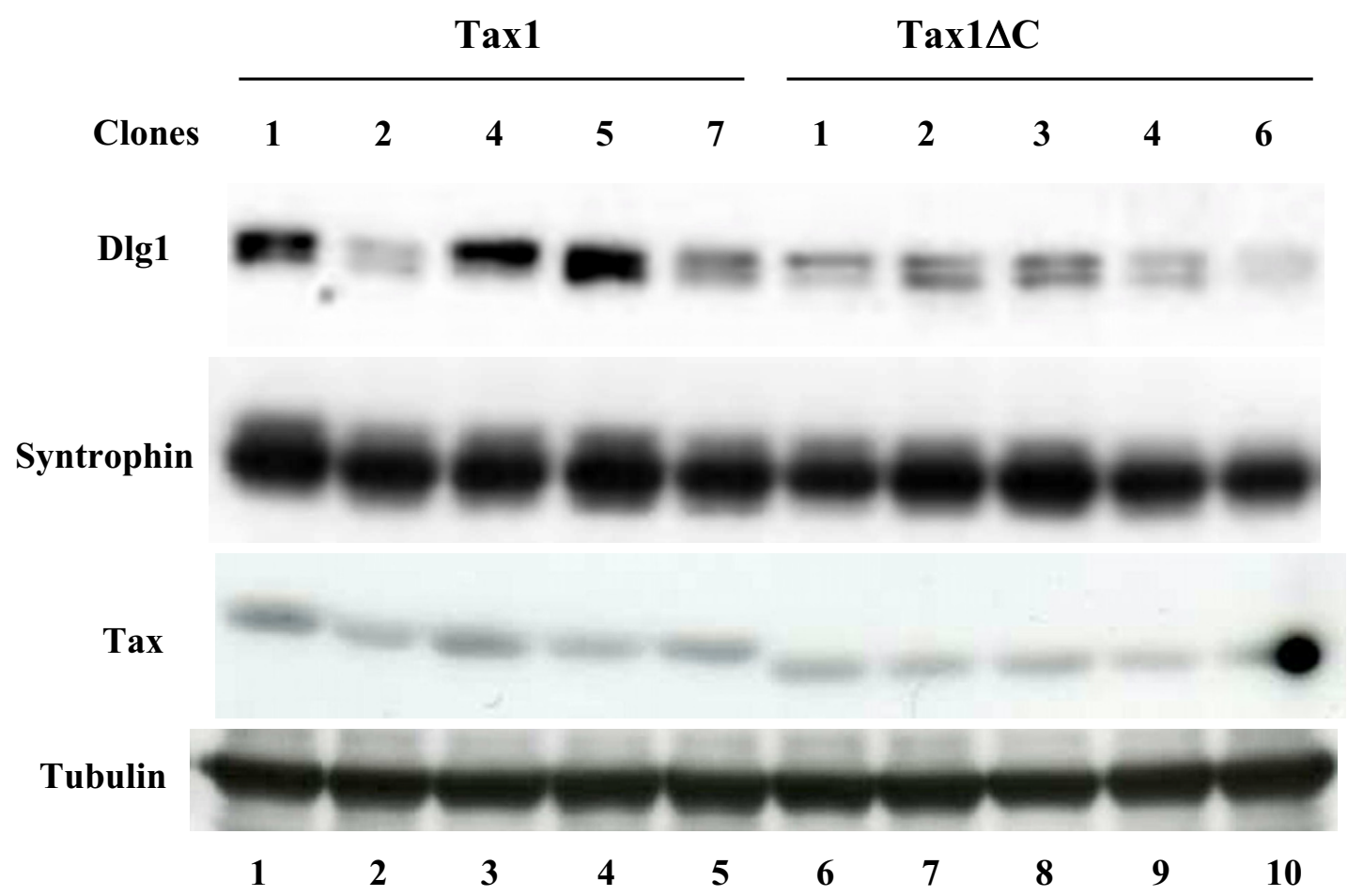

\section{Figure 5}

Low DIg I expression in IL-2-independent Tax I $\Delta$ C clones. CTLL-2 cells were infected with TaxI-virus (lanes I-5) or $\operatorname{Tax} \mid \Delta C$-virus (lanes 6-10), and seeded in 96-well plates in the absence IL-2 for more than one month. The expression of DIg I (top), Syntrophin $\beta$ (second column), TaxI (third column), or Tubulin (bottom) in Taxl-transformed CTLL-2 clones (lanes 58) and $\operatorname{Tax} \mid \Delta C$-transformed clones (lane 9-12), was measured by Western blot analysis using corresponding antibodies.

were extremely rare to emerge, expressed less Dlg1 than non-transformed cells or Tax1-transformed cells (Figure 4 and 5).

All HTLV-1-transformed T-cell lines expressed low levels of Dlg1 relative to control T-cell lines (Figure 6). However, it is unlikely that reduced Dlg1 expression could be due to Tax1-induced degradation. First, unlike human papilloma virus (HPV) E6, Tax1 expression in the kidney cell line 293T did not induce degradation of Dlg1 [23]. Moreover, a human T-cell line transformed by recombinant HTLV$1 \Delta \mathrm{PBM}$ containing Tax $1 \Delta \mathrm{C}$ also possessed a low level of Dlg1 protein (Figure 6). Taken together with the findings in CTLL-2 cells, these results suggested that Dlg1 is an inhibitory protein for HTLV-1-induced transformation of human T-cells, and low-Dlg1 expression is preferential for the HTLV-1 Tax1 function.

Dlg1 knockdown in CTLL-2 cells increased the frequency of IL-2-independent transformation induced by Tax1 (Figure 2). Given that Tax1 through the PBM can inactivate Dlg1 function [28], these results indicated that only cells expressing high amounts of Tax 1 or reduced amounts of Dlg1 acquire IL-2 independent phenotype (Figure 8A and $8 \mathrm{~B})$. This is consistent with the observation that some Tax1-transformed CTLL-2 cells expressed reduced amounts of Dlg1 relative to parental CTLL-2 cells. In addition, this explains why all the human T-cells transformed by HTLV-1 Tax1 with an intact PBM expressed relatively low amounts of Dlg1. 


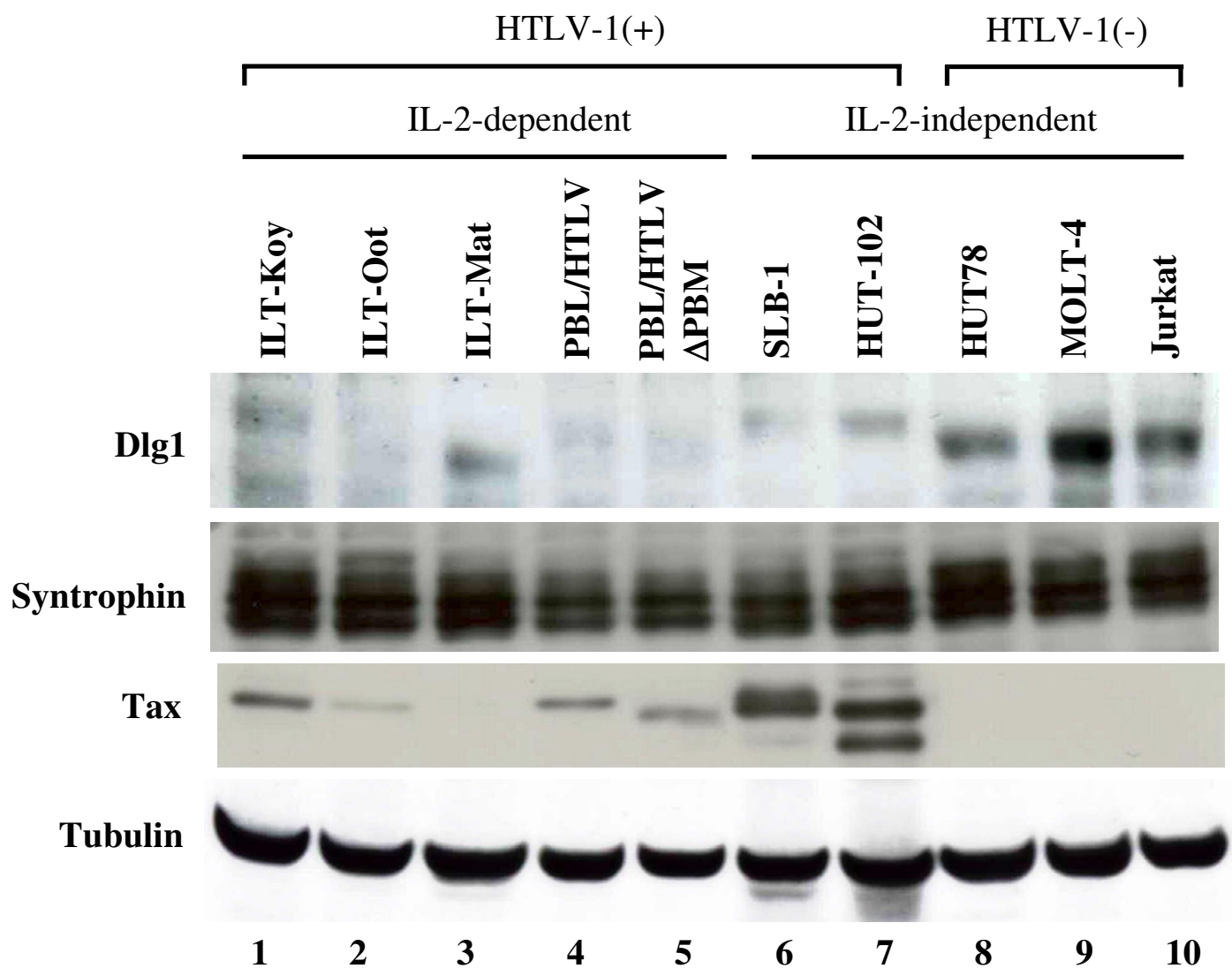

\section{Figure 6}

DIg I expression is lower in HTLV-I-transformed human T-cell lines than HTLV-I negative cell lines. Cell lysates were prepared from seven HTLV-I transformed T-cell lines (lanes I-7) and three HTLV-I negative T-cell lines (lanes 8-I0). The expression of hDIgI (top), Syntrophin $\beta$ (second column), Taxl (third column), or Tubulin (bottom) was measured by Western blot analysis using corresponding antibodies.

It is unclear how Dlg1 inhibits the transforming activity of Tax1 in CTLL-2 cells, and how such Dlg1 function is inactivated by Tax1. Previous results showed that over-expression of Dlg1 inhibited cell cycle transition from G1 to S phase in the mouse fibroblast cell line NIH3T3, which was overcome by Tax1 in a PBM-dependent manner [28]. On the other hand, Tax1 changes subcellular localization of Dlg1 from detergent soluble fraction to detergent insoluble fraction in HTLV-1-infected T-cell lines and 293T cells, suggesting that Tax1 inactivates Dlg1 function through altering the localization in cells [23]. Together, one possible scenario is that Dlg1 inhibits cell cycle progression of CTLL-2/Tax1, but Tax1 through altering localization of Dlg1 in cells, overcome the cell cycle inhibition to initiate IL-2-independent transformation.
Dlg1 knockdown did not increase transforming activity of Tax1 $\Delta$ C toward CTLL-2 cells. This finding was initially disappointing to us, since Dlg1 was a major PDZ protein interacting with Tax1 in T-cells (data not shown). This finding, however, suggested that PDZ protein(s) other than Dlg1 inhibits transformation of CTLL-2 by Tax1 (Figure 8). At least two more Tax1-interacting PDZ proteins other than Dlg1 are needed to explain the present data. As discussed above, inactivation of one of the two PDZ proteins should be essential for IL-2-independent transformation of CTLL-2 by Tax1, since Dlg1 knockdown did not enhance the frequency of cells transformed by Tax $1 \Delta \mathrm{C}$ (Figure 3). The other PDZ protein likely influences the rate of proliferation of IL-2-independent Tax1 cells, since IL-2-independent Tax $1 \Delta \mathrm{C}$ cells grew more slowly than IL- 
A)

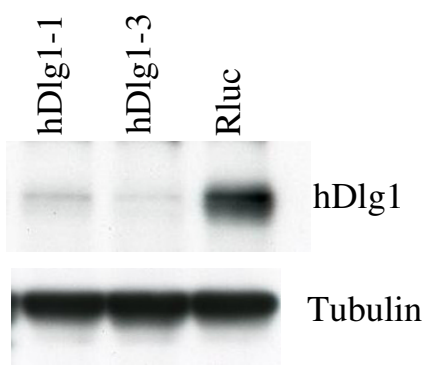

B)

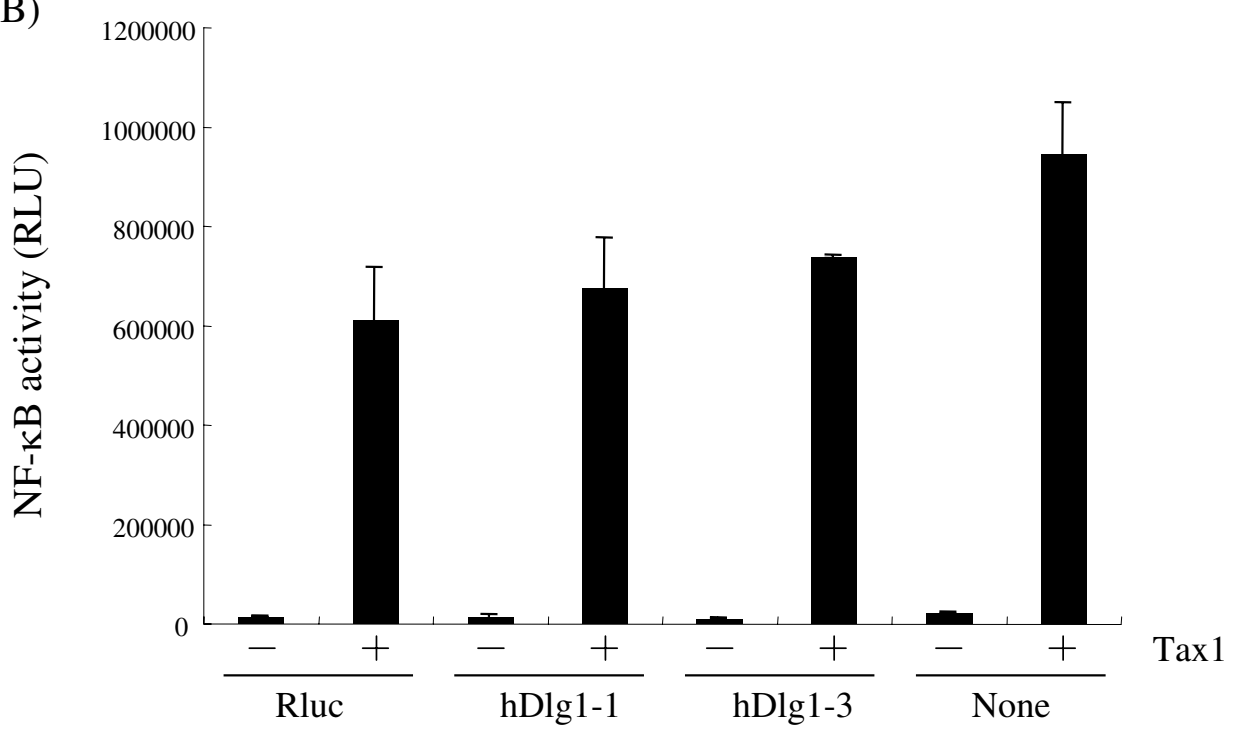

Figure 7

DIg I knockdown little affects transcriptional activity of TaxI. (A) Cell lysates were prepared from the indicated knockdown cells (hDlgI-I, hDlgl-3, Rluc), and the amounts of $\mathrm{hDlgI}$ protein and Tubulin in cell lysates were measured by Western blot analysis using anti-hDIgI antibody (top) and anti-Tubulin (bottom), respectively. (B) Jurkat cells (hDlgl-I, hDlgI3, Rluc) were transfected with $\kappa$ B-Luc plasmid together with $\mathrm{pH} \beta \mathrm{Pr}$-I-TaxI-neo plasmid using the lipofection method. Fortyeight hours after transfection, cell lysates were prepared and the luciferase activity in the lysates was measured by a luminometer. Error bars indicate standard deviations.

2-independent Tax1 cells (Fig 4). However, it should be noted that transformed Tax1 $\Delta \mathrm{C}$ cells exhibited more cell death than transformed Tax1 cells (data not shown). Thus, the latter PDZ protein might regulate apoptosis of Tcells expressing Tax1. There are several Tax1-interacting PDZ proteins, such as MAGI-3 and the precursor of IL-16 [30]. In addition, there are three Dlg1 family members, such as Chapsyn-110 (PSD-93), NE-Dlg (SAP102), and PSD-95 (SAP90) [36], although it is unclear whether they are expressed in T-cells. Therefore, the identification of PDZ proteins other than Dlg1 that are involved in Tax1 function is crucial to elucidate the mechanism of T-cell transformation by HTLV-1.

\section{Conclusion}

The Tax1 PBM is conserved in all known HTLV-1 isolates but not in HTLV-2 isolates. Similarly, the E6 oncoprotein derived from high-risk HPVs, but not low-risk HPVs, has a PBM and interacts with Dlg1. These results strongly suggest that the PBM and the interacting protein(s) play crucial roles in oncogenesis by these viruses. Approximately $12 \%$ of Dlg1 heterozygous mice developed B-cell or NK lymphomas, which suggests that Dlg1 is involved in lymphomagenesis, even when its expression is half of that of wild-type mice [32]. Thus, Dlg1 is an attractive candidate regulating not only human T-cell transformation but also ATL leukemogenesis. 


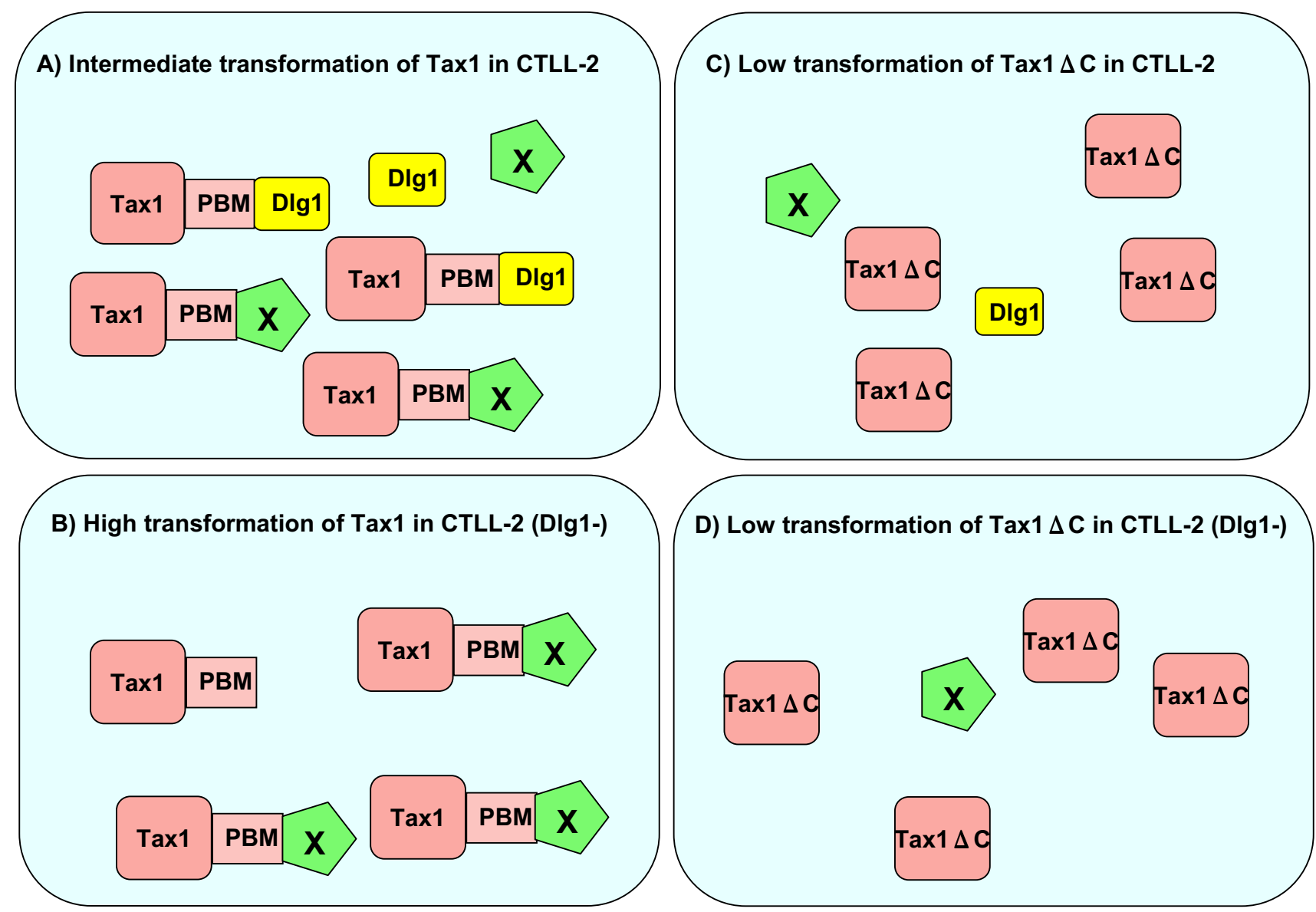

Figure 8

A model of Tax I induced transformation. A) At least two PDZ proteins, DIgl and a putative protein X, should be inactivated by Taxl for the transformation of CTLL2 cells. B) Taxl inactivates X more efficiently in DlgI knockdown cells than in CTLL-2 cells, resulting in the higher transformation rate. C, D) Tax $\Delta$ C selectively transforms CTLL2 expressing low amount of both DIgI and X. In this case, cells expressing low amount of $X$ always express low amount of DlgI.

\section{Materials and methods}

\section{Cells and cell growth assay}

CTLL-2 is a mouse cytotoxic T-cell line that grows in an IL2-dependent manner $[24,33]$. The human T-cell lines used in the present experiments have been characterized previously [23]. ILT-Koy, ILT-Oot, ILT-Mat, PBL/HTLV-1, PBL/HTLV-1 $\triangle \mathrm{PBM}$ are IL-2-dependent HTLV-1-transformed human T-cell lines, while SLB-1 and HUT-102 are IL-2-independent. PBL/HTLV-1 and PBL/HTLV-1 $\triangle$ PBM were established by recombinant wild type HTLV-1 and HTLV-1 $\triangle$ PBM with a deletion of PBM in Tax1, respectively [24]. HUT78, MOLT-4 and Jurkat are HTLV-1-negative human T-cell lines. 293T is a human embryonic kidney cell line. SLB-1, HUT-102, HUT78, MOLT-4 and Jurkat were cultured in RPMI1640 supplemented with 10\% fetal bovine serum (FBS), $4 \mathrm{mM}$ glutamine, penicillin (50 U/ $\mathrm{ml}$ ), and streptomycin (50 $\mu \mathrm{g} / \mathrm{ml})$ (RPMI/10\%FBS).
CTLL-2 cells were cultured in RPMI/10\% FBS containing 2-mercaptoethanol and $1 \mathrm{nM}$ recombinant human IL-2. IL-2-independent CTLL-2 cells stably expressing Tax1 were cultured in RPMI/10\%FBS and 2-mercaptoethanol without IL-2. IL-2-dependent human T-cell lines were cultured in RPMI/20\%FBS with 1 nM IL-2. 293T cells were cultured in Dulbecco's modified Eagle's medium supplemented with $10 \%$ FBS, penicillin $(50 \mathrm{U} / \mathrm{ml})$, and streptomycin $(50 \mu \mathrm{g} / \mathrm{ml})$.

For the cell growth assay, CTLL-2 $\left(10^{5} / \mathrm{ml}\right.$ of RPMI/ $10 \%$ FBS) were cultured with or without IL-2 in a 24 well plate. The number of viable cells was counted by the trypan blue exclusion method under a microscope. 


\section{Plasmids and oligonucleotides}

pH $\beta$ Pr-1-Tax1-neo is a Tax1 expression vector, which has a $\beta$-actin promoter and a neomycin resistance gene as a selection marker. $\kappa \mathrm{B}$-Luc is a luciferase expression plasmid regulated by the $\kappa \mathrm{B}$ element of the IL-2 receptor $\kappa$-chain gene and the minimal HTLV-1 promoter. The lentiviral expression vectors, pSIN-eGFP and CS-CDF-CG-PRE, were kindly provided by Dr. C. Boshoff (Wolfson Institute for Biomedical Research) and Dr. H. Miyoshi (RIKEN Tsukuba Institute), respectively [37]. The lentiviral expression vector pSIN-bsrEGFP was constructed by replacing the eGFP gene (a BamHI - NotI fragment) of pSIN-eGFP with the bsrEGFP gene (an EcoRI - NotI fragment) from pkB$b s r$ GFP [38]. eGFP and $b s r$ EGFP genes are an enhanced green fluorescent protein gene and a chimeric gene of eGFP with blasticidin $S$ deaminase, respectively. The lentiviral expression vector CS-CDF-CP-PRE was constructed by replacing the eGFP gene (a NheI - XhoI fragment) of CS-CDF-CG-PRE with a PCR amplified puromycin-Nacetyl-transferase gene from pIRESpuro3 (Clontech). Dlg1-1, Dlg1-3, hDlg-1, hDlg1-3, CAT, LUC, and Rluc are oligonucleotides used for the construction of short hairpin (sh)RNA-expressing plasmids against mouse dlg1 sequences (nt1092-1111 and nt2391-2410), human dlg1 (hDlg1) sequences (nt2135-2153 and nt2563-2581), chloramphenicol acetyltransferase, and renilla luciferase genes, respectively. The sequences of these oligonucleotides are 5'-ggatggcgagctttaggttggGTGTGCTGTCCccaatctgaagcttgccatccTTTTT-3' for Dlg1-1, 5'ggatgtttaggagtataagttGTGTGCTGTCCaacttatgctcctgaatatccTTTTT-3' for Dlg1-3, 5'-gaaagaacgagcccgattaTTCAAGAGAtaatcgggctcgttcttcTTTTT-3' for hDlg1-1, 5'gtgttcagtctgtacgagaTTCAAGAGAtctcgtacagact-

gaacacTTTTT-3' for hDlg1-3, 5'gagtggatgccacgacggtttGTGTGCTGTCCaaatcgtcgtggtattcactcTTTTT-3' for CAT, 5'-ggcetttcactgctcctgcgaGTGTGCTGTCCtcgtaggagtagtgaaaggccTTTTT-3' for LUC, and 5'gcctttcactactcctacgTTCAAGAGAcgtaggagtagtgaaag-

gcTTTTT-3' for Rluc. The oligonucleotides Dlg1-1, Dlg1-3, CAT, and LUC were cloned into pGEM-U6L, which has a U6 gene promoter under the control of RNA polymerase III. hDlg1-1, hDlg1-3, and Rluc were cloned into pSUPER, a gift from Dr. R. Agami (The Netherlands Cancer Institute), which has a H1-RNA gene promoter. The EcoRI fragments containing respective U6 promoter/shRNA or H1 promoter/shRNA sequences then were subcloned into the EcoRI site of pSIN-bsrEGFP or CS-CDF-CP-PRE, respectively.

To construct lentiviral expression plasmids for Tax1 (pSIN-EF-Tax), a DNA fragment containing the EF1 $\alpha$ gene promoter was amplified from pEFneo [39]. The amplified fragment was exchanged with the SFFV promoter fragment in pSIN-eGFP using EcoRI and BamHI sites (pSINEF-eGFP). To utilize the Gateway recombination system
(Invitrogen), the Gateway Reading Frame Cassette A fragment was inserted in the BamHI and NotI sites of pSIN-EFeGFP in place of eGFP (pSIN-EF-RfA). The Tax1 and Tax $1 \Delta \mathrm{C}$ coding sequences were subcloned into pENTR/DTOPO (Invitrogen), and transferred to pSIN-EF-RfA by a Gateway recombination reaction according to the manufacturers' instructions. The Tax 1 and Tax $1 \Delta \mathrm{C}$ genes were described previously [23].

\section{Establishment of knockdown cells}

Lentiviruses expressing shRNAs described above were produced according to a three plasmid one shot expression system in 293T cells [40]. These lentiviruses then were used to infect CTLL- 2 or Jurkat cells $\left(4 \times 10^{5}\right)$ in a final volume of $2.0 \mathrm{ml} \mathrm{RPMI} / 10 \%$ FBS containing $8 \mu \mathrm{g} / \mathrm{ml}$ of polybrene (Sigma) and $1 \mathrm{nM}$ IL-2 for CTLL-2. The infected CTLL-2 and Jurkat cells were cultured in the selection medium containing $14 \mu \mathrm{g} / \mathrm{ml}$ of blasticidin (Invitrogen) or $0.2 \mu \mathrm{g} / \mathrm{ml}$ of puromycin (Sigma) for more than 10 days, respectively. The expression of Dlg1 in the selected cells was examined by western blotting analysis.

\section{IL-2-independent transformation assay}

CTLL-2 cells $\left(4 \times 10^{5}\right)$ were infected with lentiviruses encoding Tax 1 or Tax $1 \Delta \mathrm{C}$ in a final volume of $2.0 \mathrm{ml}$ RPMI/10\%FBS containing $8 \mu \mathrm{g} / \mathrm{ml}$ polybrene (Sigma) and $1 \mathrm{nM}$ IL-2. At 48 hours after infection, the cells were washed twice with phosphate-buffered saline (PBS), and cultured in RPMI/10\%FBS without IL-2. For the 96-well plate assay, the infected CTLL- 2 cells were cultured (300 cells/well/0.1 ml for Tax 1 or 5000 cells/well/0.1 ml for $\operatorname{Tax} 1 \Delta \mathrm{C}$ ) without IL-2. During the culture period, the medium was changed every three days. After four weeks, the number of wells containing outgrowing cells was counted under a light microscope. Transformation efficiency (\%) was calculated as a ratio of the number of positive wells out of 96 wells.

\section{Western blotting}

CTLL-2 cells were lysed with sodium dodecyl sulfate (SDS)-sample buffer consisting of $62.5 \mathrm{mM}$ Tris- $\mathrm{HCl}(\mathrm{pH}$ $6.8), 2 \%$ SDS, $10 \%$ glycerol. Protein concentrations of the cell lysates were measured using the DC protein assay kit (Bio-Rad Laboratories). The cell lysates then were treated with $50 \mathrm{mM}$ DTT, $0.01 \%$ bromophenol blue and heated at $95^{\circ} \mathrm{C}$ for $5 \mathrm{~min}$. The resultant lysates were subjected to SDS-PAGE containing $8 \%$ acrylamide gel for Dlg1 or $10 \%$ acrylamide for Tax1, Syntrophin $\beta$ or Tubulin, and the proteins in the gel were transferred to a nitrocellulose membrane. The membrane was incubated with 5\% skim milk for $1 \mathrm{~h}$ at room temperature followed by incubation with specific antibodies shown below. After washing, the membrane was treated with a secondary antibody conjugated with horseradish peroxidase. Specific protein bands were visualized using the ECL Western blotting detection 
system (Amersham Pharmacia Biotech). Antibodies used were anti-human Dlg1 (BD Biosciences), anti-Tax1 (TAXY-7) [41], anti-Syntrophin $\beta$ (Affinity Bioreagents), and anti-Tubulin (Oncogene).

\section{Transient transfection and luciferase assays}

Jurkat cells in RPMI/10\%FBS were seeded at $4 \times 10^{5}$ cells/ well in a 12-well plate. The cells then were cotransfected with the Tax expression plasmid together with $\kappa \mathrm{B}$-Luc by using Transfectin (Bio-Rad Laboratories) according to the manufacturer's instructions. At 48 hours after transfection, cell lysates were prepared from the transfected cells, and the luciferase activity was determined using Luciferase Assay System (Promega) and a luminometer (LUMAT LB9507, Berthold).

\section{Competing interests}

The author(s) declare that they have no competing interests.

\section{Authors' contributions}

KI, MH and MT, LX, SY, and YT carried out the establishing the cell lines and the functional analysis of the cell lines. MO, ST, PG and MF participated in the experimental design, data interpretation, and writing of the manuscript.

\section{Acknowledgements}

This work was supported in part by a Grant-in-Aid for Scientific Research on Priority Areas (C) and for Scientific Research (C) of Japan and grants from the National Institutes of Health (CAI00730 and CA077556). We thank Drs. Chris Boshoff, Jun-ichi Fujisawa, Hiroyuki Miyoshi, Reuven Agami, and Mari Kannagi for the PSIN-eGFP and the pGEM-U6L plasmids, the $K B$-Luc plasmid, the CS-CDF-CG-PRE plasmid, the PSUPER plasmid, and the HTLV-I-infected T-cell lines, respectively. We thank the Takeda pharmaceutical company for providing recombinant human IL-2. We also thank Chika Yamamoto for excellent technical assistance and Kathleen Hayes for assistance in editing the manuscript.

\section{References}

I. Takatsuki K: Discovery of adult T-cell leukemia. Retrovirology 2005, 2(1): 16 .

2. Uchiyama T, Yodoi J, Sagawa K, Takatsuki K, Uchino H: Adult T-cell leukemia: clinical and hematologic features of 16 cases. Blood 1977, 50(3):48I-492.

3. Matsuoka M: Human T-cell leukemia virus type I (HTLV-I) infection and the onset of adult T-cell leukemia (ATL). Retrovirology 2005, 2(I):27.

4. Poiesz BJ, Ruscetti FW, Gazdar AF, Bunn PA, Minna JD, Gallo RC: Detection and isolation of type $C$ retrovirus particles from fresh and cultured lymphocytes of a patient with cutaneous T-cell lymphoma. Proc Natl Acad Sci U S A 1980 , 77(I2):7415-7419.

5. Hinuma $Y$, Nagata K, Hanaoka M, Nakai M, Matsumoto T, Kinoshita $\mathrm{KI}$, Shirakawa S, Miyoshi I: Adult T-cell leukemia: antigen in an ATL cell line and detection of antibodies to the antigen in human sera. Proc Natl Acad Sci U S A 198I, 78( I 0):6476-6480.

6. Miyoshi I, Kubonishi I, Yoshimoto S, Akagi T, Ohtsuki Y, Shiraishi Y, Nagata K, Hinuma $Y$ : Type $C$ virus particles in a cord $T$-cell line derived by co-cultivating normal human cord leukocytes and human leukaemic T cells. Nature I98I, 294(5843):770-77I.

7. Yamamoto N, Okada M, Koyanagi Y, Kannagi M, Hinuma Y: Transformation of human leukocytes by cocultivation with an adult $\mathbf{T}$ cell leukemia virus producer cell line. Science 1982 , 2I7(456I):737-739.

8. Hall WW, Fujii M: Deregulation of cell-signaling pathways in HTLV-I infection. Oncogene 2005, 24(39):5965-5975.

9. Grassmann R, Aboud M, Jeang KT: Molecular mechanisms of cellular transformation by HTLV-I Tax. Oncogene 2005, 24(39):5976-5985.

10. Grassmann R, Berchtold S, Radant I, Alt M, Fleckenstein B, Sodroski JG, Haseltine WA, Ramstedt U: Role of human T-cell leukemia virus type I $\mathbf{X}$ region proteins in immortalization of primary human lymphocytes in culture. J Virol 1992, 66(7):4570-4575.

II. Akagi T, Shimotohno K: Proliferative response of Taxl-transduced primary human T cells to anti-CD3 antibody stimulation by an interleukin-2-independent pathway. J Virol 1993 , 67(3): $12 \mid 1-1217$.

12. Grossman WJ, Kimata JT, Wong FH, Zutter M, Ley TJ, Ratner L: Development of leukemia in mice transgenic for the tax gene of human T-cell leukemia virus type I. Proc Natl Acad Sci US A 1995, 92(4): 1057-1061.

13. Hasegawa H, Sawa H, Lewis MJ, Orba $Y$, Sheehy N, Yamamoto $Y$, Ichinohe $\mathrm{T}$, Tsunetsugu-Yokota $\mathrm{Y}$, Katano $\mathrm{H}$, Takahashi $\mathrm{H}$, Matsuda J, Sata T, Kurata T, Nagashima K, Hall WW: Thymus-derived leukemia-lymphoma in mice transgenic for the Tax gene of human T-lymphotropic virus type I. Nat Med 2006, I2(4):466-472.

14. Lairmore MD, Silverman L, Ratner L: Animal models for human T-lymphotropic virus type I (HTLV-I) infection and transformation. Oncogene 2005, 24(39):6005-60I5

15. Maruyama M, Shibuya H, Harada H, Hatakeyama M, Seiki M, Fujita T, Inoue J, Yoshida M, Taniguchi T: Evidence for aberrant activation of the interleukin-2 autocrine loop by HTLV-I-encoded p40x and T3/Ti complex triggering. Cell I987, 48(2):343-350.

16. Ballard DW, Bohnlein E, Lowenthal JW, Wano Y, Franza BR, Greene WC: HTLV-I tax induces cellular proteins that activate the kappa B element in the IL-2 receptor alpha gene. Science 1988, 24 I(4873): 1652-1655.

17. Fujii M, Tsuchiya H, Chuhjo T, Akizawa T, Seiki M: Interaction of HTLV-I TaxI with p67SRF causes the aberrant induction of cellular immediate early genes through CArG boxes. Genes Dev 1992, 6(I I):2066-2076.

18. Iwai K, Mori N, Oie M, Yamamoto N, Fujii M: Human T-cell leukemia virus type I tax protein activates transcription through AP-I site by inducing DNA binding activity in T cells. Virology 200I, 279(I):38-46.

19. Sun SC, Yamaoka S: Activation of NF-kappaB by HTLV-I and implications for cell transformation. Oncogene 2005, 24(39):5952-5964.

20. Peloponese JM Jr., Jeang KT: Role for Akt/protein kinase B and AP-I in cellular proliferation induced by the human T-cell leukemia virus type I (HTLV-I) tax oncoprotein. J Biol Chem 2006, 28 I (I3):8927-8938.

21. Feuer G, Green PL: Comparative biology of human T-cell lymphotropic virus type I (HTLV-I) and HTLV-2. Oncogene 2005, 24(39):5996-6004

22. Endo K, Hirata A, Iwai K, Sakurai M, Fukushi M, Oie M, Higuchi M, Hall WW, Gejyo F, Fujii M: Human T-cell leukemia virus type 2 (HTLV-2) Tax protein transforms a rat fibroblast cell line but less efficiently than HTLV-I Tax. J Virol 2002, 76(6):2648-2653

23. Hirata A, Higuchi M, Niinuma A, Ohashi M, Fukushi M, Oie M, Akiyama T, Tanaka Y, Gejyo F, Fujii M: PDZ domain-binding motif of human T-cell leukemia virus type I Tax oncoprotein augments the transforming activity in a rat fibroblast cell line. Virology 2004, 318(I):327-336.

24. Xie L, Yamamoto B, Haoudi A, Semmes OJ, Green PL: PDZ binding motif of HTLV-I Tax promotes virus-mediated T-cell proliferation in vitro and persistence in vivo. Blood 2006, 107(5): $1980-1988$

25. Tsubata C, Higuchi M, Takahashi M, Oie M, Tanaka Y, Gejyo F, Fujii M: PDZ domain-binding motif of human T-cell leukemia virus type I Tax oncoprotein is essential for the interleukin 2 independent growth induction of a T-cell line. Retrovirology 2005, 2:46.

26. Kiyono $T$, Hiraiwa $A$, Fujita $M$, Hayashi $Y$, Akiyama $T$, Ishibashi $M$ : Binding of high-risk human papillomavirus E6 oncoproteins to the human homologue of the Drosophila discs large 
tumor suppressor protein. Proc Natl Acad Sci U S A 1997, 94(2I): $|16| 2-1|6| 6$.

27. Rousset R, Fabre S, Desbois C, Bantignies F, Jalinot P: The C-terminus of the HTLV-I Tax oncoprotein mediates interaction with the PDZ domain of cellular proteins. Oncogene 1998, I 6(5):643-654.

28. Suzuki T, Ohsugi Y, Uchida-Toita M, Akiyama T, Yoshida M: Tax oncoprotein of HTLV-I binds to the human homologue of Drosophila discs large tumor suppressor protein, hDLG, and perturbs its function in cell growth control. Oncogene 1999, 18(44):5967-5972.

29. Ohashi M, Sakurai M, Higuchi M, Mori N, Fukushi M, Oie M, Coffey RJ, Yoshiura K, Tanaka Y, Uchiyama M, Hatanaka M, Fujii M: Human T-cell leukemia virus type I Tax oncoprotein induces and interacts with a multi-PDZ domain protein, MAGI-3. Virology 2004, 320(I):52-62.

30. Wilson KC, Center DM, Cruikshank WW, Zhang Y: Binding of HTLV-I tax oncoprotein to the precursor of interleukin-16, a T cell PDZ domain-containing protein. Virology 2003, 306(I):60-67.

31. Woods DF, Bryant PJ: The discs-large tumor suppressor gene of Drosophila encodes a guanylate kinase homolog localized at septate junctions. Cell |99|, 66(3):45I-464.

32. Aiba T, Kohu K, Ishidao T, Yasui N, Horii A, Aburatani H, Akiyama T: The mammalian homolog of the Drosophila discs large tumor suppressor protein up-regulates expression of the ELR+ CXC chemokine Scyb5. Biochem Biophys Res Commun 2005, 337(I): $191-194$

33. Iwanaga $Y$, Tsukahara T, Ohashi T, Tanaka $Y$, Arai M, Nakamura $M$, Ohtani K, Koya Y, Kannagi M, Yamamoto N, Fujii M: Human T-cell leukemia virus type I tax protein abrogates interleukin-2 dependence in a mouse T-cell line. I Virol 1999, 73(2): $127 \mid-1277$.

34. Kuo YL, Giam CZ: Activation of the anaphase promoting complex by HTLV-I tax leads to senescence. Embo J 2006, 25(8): $174|-| 752$.

35. Lee SS, Weiss RS, Javier RT: Binding of human virus oncoproteins to hDIg/SAP97, a mammalian homolog of the Drosophila discs large tumor suppressor protein. Proc Natl Acad Sci U S A 1997, 94(13):6670-6675.

36. Funke L, Dakoji S, Bredt DS: Membrane-associated guanylate kinases regulate adhesion and plasticity at cell junctions. Annu Rev Biochem 2005, 74:219-245.

37. Godfrey A, Anderson J, Papanastasiou A, Takeuchi Y, Boshoff C: Inhibiting primary effusion lymphoma by lentiviral vectors encoding short hairpin RNA. Blood 2005, 105(6):25I0-25I8.

38. Higuchi M, Matsuda T, Mori N, Yamada Y, Horie R, Watanabe T, Takahashi M, Oie M, Fujii M: Elevated expression of CD30 in adult T-cell leukemia cell lines: possible role in constitutive NF-kappaB activation. Retrovirology 2005, 2(I):29.

39. Asao H, Fu XY: Interferon-gamma has dual potentials in inhibiting or promoting cell proliferation. J Biol Chem 2000, 275(2):867-874

40. Dull T, Zufferey R, Kelly M, Mandel RJ, Nguyen M, Trono D, Naldini $L$ : A third-generation lentivirus vector with a conditional packaging system. J Virol I 998, 72( I I):8463-847I.

41. Tanaka Y, Yoshida A, Tozawa H, Shida H, Nyunoya H, Shimotohno K: Production of a recombinant human T-cell leukemia virus type-I trans-activator $(\operatorname{tax} I)$ antigen and its utilization for generation of monoclonal antibodies against various epitopes on the tax I antigen. Int J Cancer I99I, 48(4):623-630.

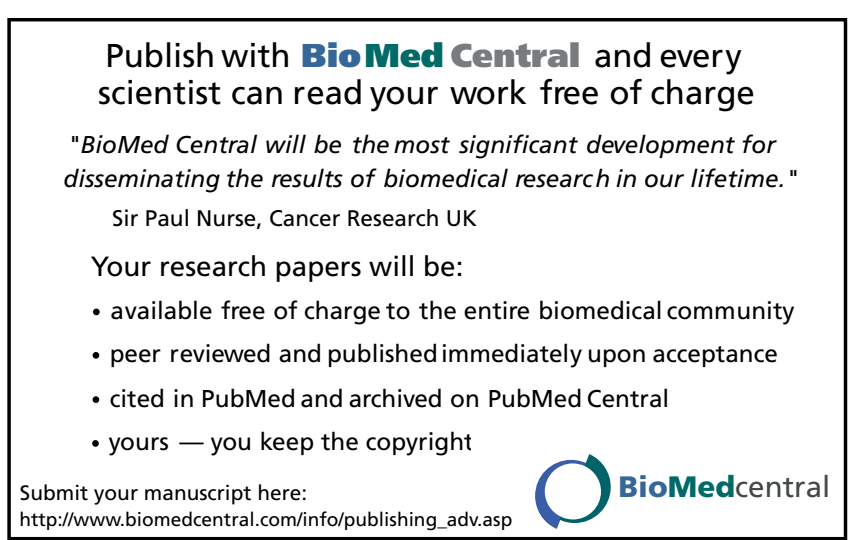

